\section{How the earth moved . . .}

\section{San Francisco}

Although Santa Cruz was the city closest to the epicentre of California's Loma Prieta earthquake on 17 October, the damage was worse in west Oakland and parts of San Francisco, a consequence of the way that complex local geology transmits the earthquake's energy. After travelling around the entire Bay Area to survey the degree of ground motion, two teams of researchers from the United States Geological Survey (USGS) in Golden, Colorado, have made a preliminary estimate of the magnitude of the Loma Prieta earthquake according to the Modified Mercalli intensity scale, a qualitative measure of ground shaking, rather than the familiar Richter scale, which measures the energy released at the epicentre.

The Mercalli scale runs from I to XII, with magnitude I being imperceptible and magnitude XII corresponding to complete destruction. A rating of VIII, which was assessed by the USGS researchers for Santa Cruz and its immediate vicinity, is characterized as the threshold of structural damage to buildings - wood-framed houses move on their foundations and unreinforced masonry walls tumble to the ground. But the localities that suffered the greatest destruction, west Oakland (where the Cypress section of Interstate highway 800 collapsed) and the Marina and Market Street areas of San Francisco, were assigned a IX rating.

Researchers suspect that thick deposits of alluvium near these heavily damaged areas amplified seismic waves. Alluvial layers of unconsolidated sediments and mud ring the perimeter of San Francisco Bay up to 200 feet thick, responding like "a bowl of jelly", absorbing and amplifying the seismic waves passing through the rock beneath, according to USGS geophysicist Paul Thenhaus.

As a result, he said, "it's not unusual to get higher ground motions at long distances from the epicentre in a large earthquake". Indeed, similar circumstances beset the 8.1 magnitude (Richter) earthquake on 19 September 1985 that devastated large parts of Mexico City. Even though the earthquake's epicentre was $350 \mathrm{~km}$ away, the city suffered widespread damage because its central and eastern portions are largely on an old lakebed.

The Mercalli rating does not provide a completely clear picture of the Loma Prieta event. Single-storey buildings in Santa Cruz fared much worse than those in San Francisco and Oakland, although the latter were shaken harder. The discrepancy results from differences in propagation between low- and highfrequency seismic waves, and from varying resonances of different kinds of building (see Nature 341, 676; 1989). Also clouding ground effects. the analysis was the liquefaction of sandy soils, particularly in the San Francisco Marina district, which led to serious damage even though the ground motion was relatively small in that area. To corroborate their assessments, the USGS teams studied areas of similar damage that appeared to be uninfluenced by such

In addition to their direct observations, the researchers incorporated results from
1,313 questionnaires, distributed to postmasters and police and fire stations around California and in parts of western Nevada and southern Oregon, asking for eye-witness accounts of the effects of the earthquake. Not all the forms, which include 63 questions with up to seven different answers each, have been returned. Carl Stover, head of the US Earthquakes Project for the USGS, does not expect a final report, incorporating data from research papers and other sources, to be complete for two years.

Robert Buderi

\title{
. . . and the pollution didn't
}

\section{San Francisco}

When the San Francisco Bay Bridge, a section of which collapsed during last month's earthquake, reopened on 17 November after its month-long closure, local air-quality officials at first reported that the shutdown, which forced many commuters to leave their cars at home and travel instead by ferries and trains, had led to a measurable fall in air pollution from automobile emissions.

But now officials of the Bay Area Air Quality Management District (BAAQMD) admit they may have spoken too soon. An array of complications, including weather and heavier-thannormal car traffic on other bridges, seems to have made doubtful the hoped-for "case study' of what would happen if people did not use the Bay Bridge.

Researchers are now saying that they have no scientific evidence for cleaner air during the bridge closure, a great disappointment to BAAQMD's board of directors, which had hoped to drive home to the public the benefits of staying off the roads.

The San Francisco Bay Area, with some 5.5 million residents, is the fourth-largest US metropolitan area. Before the earthquake, 243,000 vehicles crossed the San Francisco Bay Bridge daily, and the area's four other main bridges carried a total of 273,000 vehicles. These cars, trucks and buses contributed half of the 500 tons of hydrocarbons released daily into the atmosphere, and 90 per cent of the 3,000 tons of carbon monoxide. Of the two, hydrocarbons, which are precursors to the formation of ozone and thence of smog, are regarded by air-quality officials as the more serious pollutant.

At first, BAAQMD officials simply removed the Bay Bridge vehicles from their calculations, and guessed there should have been a 6.7 per cent reduction in hydrocarbon and carbon monoxide levels while the bridge was closed. But figures collected at four alternative bridges showed their traffic went up to 435,000 vehicles a day during the Bay
Bridge closure, making up two-thirds of the difference. Moreover, the extra traffic caused heavy congestion, and according to James Sandberg, section chief of meterology and data analysis for the airquality district, in slow-moving traffic the emission per car goes up.

Added to this complication is the fact that ozone forms only when the weather is warm enough to provide the radiant energy to drive the needed photochemical reactions. And during hot weather an inversion layer of warm air sits over the surface, trapping and concentrating pollutants.

In the moderate Bay Area climate, ozone levels have never exceeded federal standards from mid-October until early spring. "It's just not our ozone season", said Milton Feldstein, BAAQMD's airpollution control officer.

Even if all the cars in the area had stayed off the roads, there probably would not have been a measurable change in ozone levels.

"I hate to say maybe we should have had the earthquake in September when it was nice and warm, because they'll lynch me", said Feldstein.

The end result is that ozone levels during the Bay Bridge closure were down slightly, but did not go beyond the bounds of normal seasonal variations, making any useful scientific conclusion impossible. But that does not mean the unique case study of the failed bridge is a total loss. Researchers are now trying to determine more exactly the number of cars on the road in the month following the earthquake.

Taking into account the slower speeds caused by increased congestion, they will then try to make a more accurate projection of emissions reductions and create a computer model to see if the decrease in emissions would have made a difference in ozone season. Feldstein said that BAAQMD might then still obtain evidence to convince people of the virtue of staying off the road.

Robert Buderi

NATURE · VOL $342 \cdot 7$ DECEMBER 1989 